\title{
IAMJ
}

INTERNATIONAL

AYURVEDIC

MEDICAL JOURNAL

\section{A CASE REPORT OF KASISADI OIL - AN ECONOMICAL ALTERNATIVE TO BREAST IMPLANTS}

\author{
Varsha Gaikwad Anand ${ }^{1}$, Ashwini Shitre² \\ ${ }^{1}$ Assistant Professor PhD Scholar, Department of Prasutitantra and Stri Roga D.Y. Patil School of Ayurveda, \\ Nerul 400706., Maharashtra, India \\ ${ }^{2}$ Professor \& HOD PhD guide, Department of Kaumarbhritya Shri Vivekananda Nursing home trust's Ayurved \\ college, Ahmednagar, India
}

Corresponding Author: drvarshagkwd@gmail.com

\section{https://doi.org/10.46607/iamj13p5042021}

(Published online: May 2021)

Open Access

(C) International Ayurvedic Medical Journal, India 2021

Article Received: 12/04/2021 - Peer Reviewed: 07/05/2021 - Accepted for Publication: 12/05/2021

\section{Check for updates}

\begin{abstract}
Nowadays as the impact of social media is increasing, more and more youngsters (especially girls in this case) are under pressure to look good and maintain a perfect figure as they see on screen due to which many young girls develop body image complex. Body image complex is a phenomenon wherein people are not happy with the way their body looks and as a result of which they are disturbed psychologically, they lack confidence some may even cut down on their social appearances. In Ayurveda ideal breasts (Stana Sampad) ${ }^{1}$ are described as not too huge or not too small (hypoplastic). This case study is an attempt to provide economical remedy for breast augmentation/ breast enlargement.
\end{abstract}

Keywords: Small breasts (Breast hypoplasia), Breasts implants, kasisadi oil massage, breast enlargement/augmentation. 


\section{INTRODUCTION}

A lot of women are body shamed all over the world for being either overweight or underweight. Breast being a secondary sex organ has a lot of importance not only from aesthetic point of view but also from physiological point of view. Many women have a sense of resentment for themselves for not being able to look attractive but not all can afford to take up breast implants. Breast augmentation surgery cost in India is approximately 1-1.3 lakhs. whereas cost involved in preparation of oil would be much lesser than this. Needless to say, this remedy is devoid of any anesthetic complications, hospital stay or is accompanied with difficult breast feeding or possibility of breast cancer in future. This study is an attempt to develop an economical alternative to breast implants which can be afforded by almost all strata of society. Though benign hypoplastic breasts can cause certain mental disturbances hence addressing this issue of body image complex is essential. Small breasts have multiple aetiological factors which are explained in detail later and so does the treatment modalities. This study paves a way for future research on the same topic with larger sample size and also for the unique branch of Ayurveda i.e. - "Aesthetics in Ayurveda"

\section{Review of Literature-}

Modern View ${ }^{2}$ -

The glandular tissue of breast consists of acini that are aggregated to form lobules. Several lobules collect to form lobe. there are about 15-20 such lobes in each breast. The acini of each lobe are drained by small ducts which ultimately end in one lactiferous duct for each lobe. The ducts open on the surface of the nipple. A little proximal to the opening each duct shows a dilatation called lactiferous sinus.

Deep to the areola there are numerous modified sebaceous glands. These glands become enlarged during pregnancy and produced surface elevation or tubercles. The secretion of these glands provides a protective covering for the areola and nipple during lactation.

Breast tissue as held in the place by bundle of fibrous tissue that connected to the skin and the underlying deep fascia. These bands are referred to as the suspen- sory ligaments (or ligament of cooper). In spite of these bands the normal breast has reasonable mobility over the deep fascia and its skin can be pinched up. In the female the initial enlargement of the breast at puberty is mainly due to accumulation of fat. It is later that duct system proliferates and acini appears. considerable further proliferation takes place during pregnancy. There is partial atrophy of glandular element after the end of lactation. the breast atrophies in old age.

\section{Effects of Hormone on Breasts ${ }^{3}$ -}

\section{Effects of estrogen on the breasts: -}

- Estrogen causes development of stromal tissue of the breast,

- growth of an extensive ductile system,

- deposition of fat in breast. The lobules and alveoli of the breast develop to a slight extent under the influence of estrogen alone, but it is progesterone and prolactin that causes the ultimate determinative growth and function of these structures.

In summary, the estrogen initiate growth of the breast and of the milk producing apparatus. They are also responsible for characteristic growth an external appearance of the mature female breasts.

\section{Effects of progesterone on the breasts: -}

progesterone promotes the development of the lobules and alveoli of the breasts, causing the alveolar cells to proliferate, enlarge and becomes secretory in nature.

\section{Ayurvedic View-}

Breasts (Stana) are extra organ (Strotas) present in females body which also contains ten extra muscle (Peshis), it also has vital centers (Marma) like Stanamool and Stanarohit which have potential to cause death after some while if any trauma occurs (kalantar Pranahar). Aacharya Sushrut has also narrated that two veins in each breast is Avedhya i.e. should not be operated upon, this itself elucidates how breasts implants is a risky operation and how do it lead to several complications.

\section{Breast Hypoplasia ${ }^{4}$ (Small Breasts) -}

Varying degree of under development of the breasts are seen and young women may seek medical advice 
on this account. The size of the breast depends on the fat as much as on glandular tissue and the development of the nipple is the best guide to the latter. Hypoplasia of nipple has the same cause and treatment.

\section{CAUSES:-}

- Deficiency of ovarian hormone - in this case, there is always other evidence of the deficiency such as amenorrhoea and genital underdevelopment.

- Intrinsic defect in the gland itself - the gland may be absent, rudimentary or insensitive to hormonal stimuli. This is always the case when ovarian function is normal and when the women is not wasted.

\section{Treatment as Per Modern Medicine -}

- Estrogen:- if the cause is clearly a deficiency of ovarian hormone, then breast development can be completed by administering estrogen and progesterone for several months. Although the hormone effect is temporary, the bust measurement does not usually deteriorate materially when treatment is suspended. If the menstrual and ovarian functions are normal, there is no point in administering estrogen because the supply is already adequate, and it is the breast which are at fault.

- Diet:- encourage thin patient to increase her weight.

- Physiotherapy- Local Massage, exercise for the pectoral muscle and measures designed to improve blood supply are of limited value.

- Plastic surgery:- the placing of non irritant prosthesis deep to the breast can give satisfactory result. however, augmentation of the normal breast is generally discouraged because silicon implants of obscure subsequent mammographic pictures, being densely radio opaque. The new triglyceride implants are better in this respect, being of the same radio density as the normal breast tissue and allowing visualization of calcification. Subpectoral augmentation allows for better mammographic pictures than prepectoral augmentation and has a better cosmetic result.

Hereby presenting a case of breast hypoplasia which lead to breast augmentation within 60 days by local application of kasisadi $\mathrm{Oil}^{5}$.

Kasisadi Oil is narrated as one of the aesthetic medicines.

\section{CASE REPORT-}

History - Miss.X,

Age-24, Unmarried came to O.P.D with chief complaints of small breasts \& lack of confidence due to it. Past menstrual history - interval- 30 days, duration 45 days, regular, painless, moderate.

Present menstrual history - interval- 30 days, duration 4-5 days, regular, painless, moderate

Family history - NAD

No $\mathrm{p} / \mathrm{h} / \mathrm{o}$ any major medical /surgical illness.

Prakruti - Vata - Pitta

Agni-Visham

Koshta-Madhyam

Weight $-40 \mathrm{~kg}$

Height -5.3 inches

Breast examination-

Breast size in inches - 27.5 inches

Galactorrhoea - absent, Mastitis- absent

Breast fibroadenoma - absent

\section{Assessment Tool -}

\section{Table 1}

Breast size (in inches)

Before Treatment

After Treatment

\begin{tabular}{|l|l|l}
\hline F/U 20 DAYS & 40 DAYS & 60 DAYS
\end{tabular}

Method of Application - Patient was trained to do local application of lukewarm kasisadi Tail over both breasts in circular motion for 12 minutes over each breast once a day (at night) for a period of two months with follow up after every twenty days. Pre and post treatment reading was recorded. 


\section{Concept of Abhyang -}

Table 2: As per Ayurveda oil gets absorbed into the Dhatu as follows: ${ }^{6}$

\begin{tabular}{|l|l|}
\hline Matra & Dhatu \\
\hline 300 & Roma \\
\hline 400 & Rasa \\
\hline 500 & Rakta \\
\hline 600 & Mamsa \\
\hline 700 & Meda \\
\hline 800 & Asthi \\
\hline 900 & Majja \\
\hline 1000 & Shukra \\
\hline
\end{tabular}

\section{Observations \& Results -}

1) $1^{\text {st }}$ follow up (after 20 days) - increase in breast size by 0.5 inches.

2) $2^{\text {nd }}$ follow up (after 40 days) - increase in breast size by 1 inches.

3) $3^{\text {rd }}$ follow up (after 60 days) - increase in breast size by 1 inches.

4) After treatment course (60 days) patients breast size was 30 inches (increased by 2.5 inches).

5) Patient did not develop any other breast symptoms like mastalgia, mastitis, fibroadenoma during \& after treatment.

6) Patient's menstrual cycle was not disturbed.

\section{DISCUSSIONS}

\section{1) Probable Mode of Action of Oil Massage}

Ayurvedic view- In Sushrut Samhita, Abhyang i.e. local application of oil has been cited to lead to Dhatupushtee. Breast tissue is primarily composed of fat tissue (Meda Dhatu), so the application of kasisadi oil in breast augmentation is justified. Further Aacharya Dalhan has narrated in tika of the same Shlok that if massage is done for 700 Matras ( As described in Table 2) i.e. approximately 12 minutes, the oil will reach to fatty tissue (Meda Dhatu) which will lead to its augmentation (Dhatupushtee) leading to breast enlargement.

\section{Modern view-}

Dermal Absorption: The skin is relatively permeable to fat soluble substances and relatively impermeable to water soluble substances. Essential oil molecules are so minute that when they are applied to the skin; they are able to pass through the stratum corneum (the outer layer of the epidermis). From here the oil molecule passes through dermis, into the capillaries and into the bloodstream.

Absorption also occurs through the hair follicles and sweat ducts. There are many factors that affect absorption of an oil molecule. Both rate of circulation and the warmth of the skin increase blood flow to the surface, therefore increasing the skin's ability to absorb the oil. Circulation and warmth can be increased by massage (Abhyang).

\section{2) Probable Mode of Action of Contents of Kasisadi Oil}

A) Kasis (Ferrous sulphate, Feso4 7H2O) Rasa (Taste) - Tikta, Amla

Virya (Potency) - Ushna

Guna (Property) - Snigha, Guru, Nirmala

Kasis is also cited to cure emaciation (kshay Rogahar), so it promotes the proliferation of fatty tissue of the breast, thereby leading to its enlargement.

\section{B) Gajapippali (Scindapsus officinalis) -}

Rasa-katu,

Virya - Ushna

Vipak (Post digestive metabolite) - Madhura Gajapippali by virtue of its hot properties and Madhur Vipak leads to pacification of vitiated Vatadosh. Breast hypoplasia (kshay) results from vitiated Vata Dosha hence its pacification leads to breast enlargement.
C) Ashwagandha (Withania Somnifera)
Rasa-Madhur, kashaya, tikta
Virya-Ushna
Vipak-Madhur 
In addition to being excellent Vatashamak, Ashwagandha is also Rasayan (rejuvenating) \& Vajikaran (aphrodisiac) which aids in better production of Shukra Dhatu (oestrogen \& progesterone) and breast being a secondary sex organ directly influences its growth.

D) Shatavari (Asparagus racemosa) -

Rasa-Madhura

Virya-Sheeta

Vipaka-Madhura

All the characteristics of Shatavari are Vatapittashamak, also its Rasayan (rejuvenating) i.e. leading to new and superior body tissue production, Balya i.e. imparting better strength to body tissues (here firm contour of breasts). It's an excellent Galactogogue (Stanyajanan), so it has action on both breasts (Aashray) \& milk (Aashryee).

E) Sesame oil (Til Tail)-

Breast Hypoplasia (kshay) is a result of either vitiated Vatadosha or Vata being predominant component of one's body constitution (Prakriti).

Oil massage (Abhyang) is first line of treatment of Vatadosha as skin is one of the organ where Vata resides hence massage of breast with lukewarm oil like sesame which in itself is the best remedy for Vitiated Vata Dosha, hits the target with double action. It also serves as a vehicle to deliver the contents of kasisadi oil to muscles, fatty tissue and production of oestrogen \& progesterone (Mamsa, Meda \& Shukra Dhatu)

\section{CONCLUSIONS}

Oil massage (Abhyang) leads to production of body tissues exactly in the same way as a seed starts germinating once it is watered ${ }^{7}$. Kasisadi oil serves as an economical alternative to breast implants. Contents of kasisadi oil are very wisely chosen \& each one of them has their own unique action in breast augmentation. Breast hypoplasia (small breasts) is a cause of significant mental disturbance in certain individuals. In addition to treating breast hypoplasia, efforts should be made to train individuals to focus on their strength rather than weaknesses, this will help in reducing incidences of Body image complex. Lot of young girls should be taught that confidence stems from the way how you see yourself rather than how other people see you!

\section{REFERENCES}

1. Premvati Tiwari, Ayurvediya Prasuti Tantra Evum Stree Roga, Stanya Evum Dhatree Prakaran, Chaukhambha orientalia, Varanasi, 2009, second edition, page no -646

2. Inderbir Singh, Textbook of anatomy with colour altas, Pectoral region Axilla \& Breast, Jaypee brother medical publisher (p) ltd, New Delhi, 2007, edition fourth, page no $-185,186$

3. John E Hall, Guyton and hall Text book of medical physiology, Female physiology before pregnancy \& female hormones, Elsevier, Philadelphia, $11^{\text {th }}$ edition, page no - 1017, 1018

4. Neerja Bhatla, Jeffcoate's principles of Gynaecology, Breast function \& its disorders

5. Butterworth - Heinemann, London, $5^{\text {th }}$ edition, page no $-136$

6. Indradev Tripathi, Chakradatta Samhita, Streeroga Chikitsa Aadhyay 63/56, Chaukhambha orientalia, Varanasi, 2008, page no-392.

7. Aacharya Priyavat Sharma, Sushrut Samhita,Dalhan Tika Chikitsasthan 24/30, Chaukhambha orientalia Varanasi, 2002, Second edition, page no-488.

8. Aacharya Priyavat Sharma, Sushrutsamhita, Dalhan Tika Chikitsasthan 30/32, Chaukhambha orientalia Varanasi, 2002, Second edition, page no-358.

\section{Source of Support: Nil \\ Conflict of Interest: None Declared}

How to cite this URL: Varsha Gaikwad Anand \& Ashwini Shitre: A Case Report Of Kasisadi Oil - An Economical Alternative To Breast Implants. International Ayurvedic Medical Journal \{online\} 2021 \{cited May, 2021\} Available from:

http://www.iamj.in/posts/images/upload/2950_2954.pdf 